ISBN 978-93-84468-94-1

International Conference on Education, Business and Management (ICEBM-2017)

Bali (Indonesia) Jan. 8-9, 2017

\title{
Consumer Behavior on Shopping for Cosmetics through Internet of Kasem Bundit University Chinese Students
}

\author{
Associate Professor Sutham Pongsamran, Chow Muey Shu \\ Post graduate School of business administration Kasembundit University, Bangkok \\ planning@kbu.ac.th
}

\begin{abstract}
The purpose of this study is to determine marketing mix factors affecting consumer behavior on shopping for cosmetics through Internet of Kasem Bundit University Chinese Students. The samples were selected from 215 Kasem Bundit University Chinese Students by using a check list and rating scale questionnaire as a tool. Statistical application used for data analysis was percentage, mean, standard deviation, Chi Square, and regression analysis. Findings indicated that most of respondents were females, age 23-27 years old, single marital status, average monthly income 15,000-20,000 baht, average internet usage for the period of 3-4 hours, used internet service less than one year, products that purchased were skin care and cosmetics at the end of month when friends mentioned it. The average picture of the opinions of marketing mix factors were in high level which consisted of distribution channel aspect, prices aspect, marketing promotion, and prices. The factors of personal different such as type of products, quantity of products, reason to purchase, who persuade to buy, how often to buy, and distribution channel affected the consumer behavior on shopping for cosmetics. Factors of marketing mix such as products quality, prices cheaper than traditional channel, open 24 hours, promotion with free gift with purchased correlated with consumer behavior on shopping for cosmetics through Internet at significant level 0.05 .

Recommendations from the study were that Internet cosmetics suppliers should be given priority in the design of the Website to find it easy to shop for cosmetics on the Internet. For products, prices aspect, have a payment method in different ways, more channel of payments, ease of ordering merchandises, free shipment, 24 hours service operation, and promotion with discount and free gift, in addition, attractive advertising on the internet.
\end{abstract}

Keyword: Consumer Behavior

\section{Introduction}

Electronic commerce, commonly written as E-Commerce or ecommerce, is the trading or facilitation of trading in products or services using computer networks, such as the Internet or online social networks. Electronic commerce draws on technologies such as mobile, electronic funds transfer, supply chain management, marketing, online, electronic data interchange (EDI), inventory management systems, and automated data collection systems. Modern electronic commerce typically uses the World Wide Web for at least one part of the transaction's life cycle although it may also use other technologies such as e-mail.

E-commerce businesses may employ some or all of the following:

- Online shopping web sites for retail sales direct to consumers

- Providing or participating in online marketplaces, which process third-party business-to-consumer or consumer-to-consumer sales

- Business-to-business buying and selling 
- Gathering and using demographic data through web contacts and social media

- Business-to-business electronic data interchange

- Marketing to prospective and established customers by e-mail or fax (for example, with newsletters)

- Engaging in retail for launching new products and services

- Online financial exchanges for currency exchanges or trading purposes

Global trends, in 2010, the United Kingdom had the biggest e-commerce market in the world when measured by the amount spent per capita. As of 2013, the Czech Republic was the European country where ecommerce delivers the biggest contribution to the enterprises' total revenue. Almost a quarter $(24 \%)$ of the country's total turnover is generated via the online channel.

Among emerging economies, China's e-commerce presence continues to expand every year. With 668 million internet users, China's online shopping sales reached $\$ 253$ billion in the first half of 2015, accounting for $10 \%$ of total Chinese consumer retail sales in the same period. The Chinese retailers have been able to help consumers feel more comfortable shopping online. E-ommerce transactions between China and other countries increased 32\% to 2.3 trillion yuan ( $\$ 375.8$ billion) in 2012 and accounted for $9.6 \%$ of China's total international tradeIn 2013, Alibaba had an e-commerce market share of $80 \%$ in China. In 2014, there were 600 million Internet users in China (twice as many than in the US), making it the world's biggest online market. China is also the largest e-commerce market in the world by value of sales, with an estimated US $\$ 899$ billion in 2016.

From introduction above, researcher is interested in studying of consumer behavior on shopping for Cosmetics through Internet of Kasem Bundit University Chinese students and use the results from the study for planning to start Internet business in the future.

From introduction above, researcher are interested in determining consumer behavior and marketing mix on shopping for cosmetics through Internet of Kasem Bundit University Chinese Students and use the results to plan for opening e-commerce in the future.

\section{Purpose of the study}

The purpose of this study is to determine consumer behavior and marketing mix on shopping for cosmetics through Internet of Kasem Bundit University Chinese Students.

\section{Research Methodology}

\subsection{Sample selection}

The samples were selected from 215 Kasem Bundit University Chinese Students

\subsection{Data collection procedure}

The questionnaires were distributed to sample of 215 Kasem Bundit University Chinese Students. A total of 215 usable questionnaires were returned back to the researcher, yielding a 100 percent response rate and no missing data.

\subsection{Results of the study}

The results of the study to determine marketing mix factors affecting consumer behavior on shopping for cosmetics through Internet of Kasem Bundit University Chinese Students.

Overview of marketing mix factors affecting consumer behavior on shopping for cosmetics through Internet of Kasem Bundit University Chinese Students. 


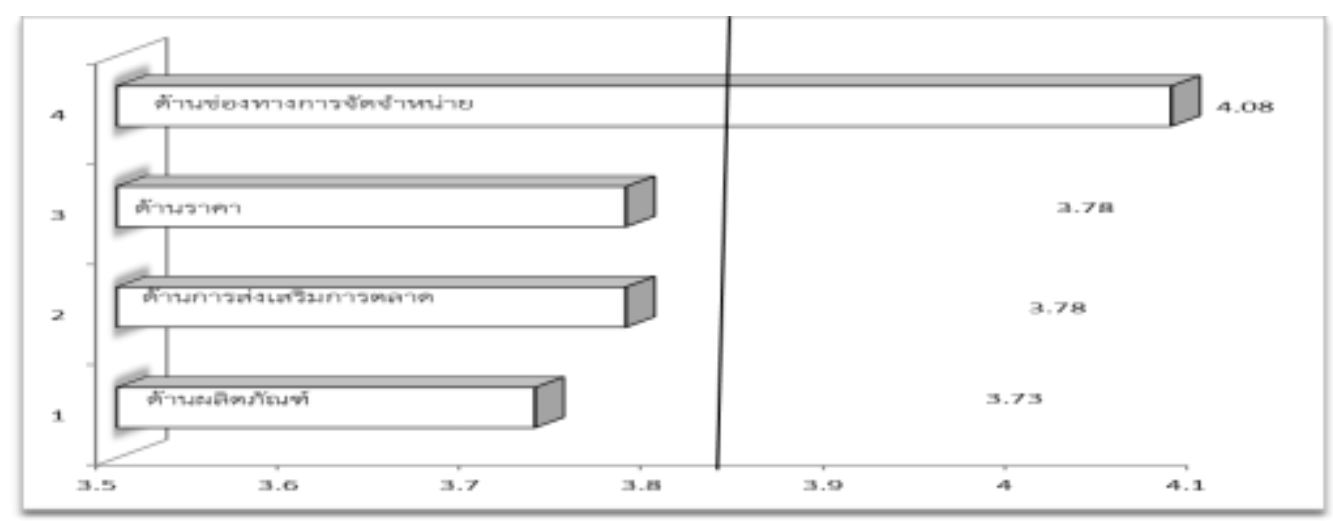

The overall picture of the opinion of marketing mix factors

Findings indicated that the picture of the opinions of marketing mix factors as distribution channel aspect were in high level $(\bar{x}=4.08)$, prices and marketing promotion aspect were at second level $(\bar{x}=3.78)$, products aspect $(\bar{x}=3.73)$, respectively.

Comparison of relationship between factors of marketing mix and consumer behavior on shopping for cosmetics through Internet of Kasem Bundit University Chinese Students.

\begin{tabular}{|c|c|c|c|c|c|c|}
\hline $\begin{array}{l}\text { Marketing mix and consumer behavior on } \\
\text { shopping for cosmetics }\end{array}$ & B & Std. error & Beta & $\mathrm{t}$ & Sig. & results \\
\hline (Constant) & .031 & .156 & & .081 & .936 & Not related \\
\hline \multicolumn{7}{|c|}{ Products aspect } \\
\hline 1. Variety of products & .058 & .053 & .071 & 1.099 & .273 & Not related \\
\hline 2. Modern products & -.026 & .060 & .030 & -.425 & .671 & Not related \\
\hline 3. Quality products & .154 & .058 & .171 & 2.666 & $.008^{*}$ & Related \\
\hline 4. Exchangeable products & .042 & .044 & .053 & .960 & .339 & Not related \\
\hline 5. Service after sales & .065 & .052 & .082 & .1249 & .213 & Not related \\
\hline 6. Users friendly website & .006 & .050 & .007 & .123 & .902 & Not related \\
\hline 7. Additional information for products & .035 & .054 & .041 & .646 & .519 & Not related \\
\hline 8. $\quad$ Easy to search for products & .040 & .050 & .046 & .789 & .431 & Not related \\
\hline 9. Well-known suppliers & -.021 & .051 & -.023 & -.400 & .690 & Not related \\
\hline 10. Level of important of products & .007 & .048 & .009 & .153 & .879 & Not related \\
\hline \multicolumn{7}{|c|}{ Prices aspect } \\
\hline $\begin{array}{l}\text { 1. Prices are cheaper than other } \\
\text { channel }\end{array}$ & .127 & .049 & .138 & 2.598 & $.010^{*}$ & Related \\
\hline 2. Repayments with different methods & .067 & .049 & .071 & 1.379 & .170 & Not related \\
\hline 3. Secure payments & .011 & .048 & .012 & .227 & .821 & Not related \\
\hline 4. Prices are accurate & .093 & .059 & .114 & 1.576 & .117 & Not related \\
\hline 5. Prices are stable & -.028 & .061 & -.032 & -.462 & .645 & Not related \\
\hline \multicolumn{7}{|c|}{ Distribution channel } \\
\hline 1. Open 24 hours & .135 & .046 & .157 & 2.915 & $.004 *$ & Related \\
\hline 2. Save time to order products & .068 & .055 & .074 & 1.236 & .218 & Not related \\
\hline 3. $\quad$ Free delivery & .020 & .055 & .022 & .366 & .715 & Not related \\
\hline 4. On time delivery & .076 & .050 & .038 & .700 & .485 & Not related \\
\hline \multicolumn{7}{|c|}{ Marketing promotion } \\
\hline 1. Multimedia advertising & .035 & .050 & .038 & .700 & .485 & Not related \\
\hline 2. Attractive advertising on Internet & .011 & .045 & .013 & .245 & .807 & Not related \\
\hline 3. Promotion event, such as free gift & .171 & .054 & .182 & 3.149 & $.002 *$ & Related \\
\hline 4. Variety of promotion & .119 & .052 & .130 & 2.278 & $.024^{*}$ & Related \\
\hline
\end{tabular}

*Significant 0.05

Comparison of relationship between marketing mix and consumer behavior on shopping for cosmetics through Internet of Kasem Bundit University Chinese Students revealed that products aspect are good 
quality, prices aspect are cheaper than other distribution channel $(\mathrm{Sig}=.008 * \mathrm{Sig}=.010 *$ $\mathrm{Sig}=.004 * \mathrm{Sig}=.002 * \mathrm{Sig}=.024 *)$, distribution channels aspect are open 24 hours, marketing promotions aspect which are free gift, and discount prices correlated with consumer behavior on shopping for cosmetics through Internet with significant level 0.05 .

\section{Summary of Study Results}

The purpose of this study is to determine marketing mix factors affecting consumer behavior on shopping for cosmetics through Internet of Kasem Bundit University Chinese Students. The samples were selected from 215 Kasem Bundit University Chinese Students by using a check list and rating scale questionnaire as a tool. Statistical application used for data analysis was percentage, mean, standard deviation, Chi Square, and regression analysis.

From the results of the data analysis can be summarized as follows:

In an overview of the marketing mix factors, the average picture of the opinions were in high level details as follows:

Products aspect such as easy to search on website, modern products, user's friendly website, products exchangeable, offer more information when customers' request, and service after sales.

Prices aspect such as a variety of payment methods, prices are cheaper when purchase products online, save time when making a payment, prices are the same on the website as the prices when paying for it.

Distribution channel such as purchasing with convenient and save time, free delivery, open 24 hours a day, delivery on the schedules.

Marketing promotion such as organize promotion campaign activities, reduce prices, free gifts, and sweepstakes, etc., attractive and interesting promotion webpages, and advertising through multimedia.

\subsection{Suggestions from the study}

Recommendations from the study were that Internet cosmetics suppliers should be given priority in the design of the Website to find it easy to shop for cosmetics on the Internet. For products, prices aspect, have a payment method in different ways, more channel of payments, ease of ordering merchandises, free shipment, 24 hours service operation, and promotion with discount and free gift, in addition, attractive advertising on the internet.

\subsection{Suggestions for future research}

Consumer behavior on buying merchandise through website in Bangkok.

\section{References}

[1] Saeri Vongmonta. (2542). Consumer behavior analysis. Teera film and Sai Tech publisher, Bangkok.

[2] Thongchai Santivong. (2549). Marketing of consumer behavior. $11^{\text {th }}$ edition, Prachumchang Publisher, Bangkok.

[3] Siriwan Saerirat \& Associate. (2546). New era of marketing management. Thammasarn publisher Bangkok.

[4] Siriwan Saerirat \& Associate. (2541). Marketing strategy: case study of marketing management. Teera film and Sai Tech publisher, Bangkok.

[5] Thanaporn Bunputhatham. (2555). Factors affecting Internet users behavior on purchasing Korean Cosmetics through e-commerce in Thailand. Thesis, Master of Business Administration.

[6] Pailin Sumritpantusuk. (2555). Factors affecting women consumer on choosing high prices Facial cosmetics in Wattana district, Bangkok, Thesis, Mae Fah Luang University.

[7] Pullop Pensirinapha. (2553). Study of factors affecting undergraduate college Chinese Students on Choosing to buy medium prices of whitening cosmetics at North Bangkok College. Thesis, Master of Business Administration. North Bangkok College publisher.

[8] Buettner, Ricardo (2016). "Predicting user behavior in electronic markets based on personality-mining in large online social networks: A personality-based product recommender framework". Electronic Markets: The International Journal on Networked Business. Springer: 1-19. doi:10.1007/s12525-016-0228-z. Eurostat (18 June 2013). "Ecommerce contribution in Europe" (infographic). Retrieved 18 June. 